\title{
La influencia de la inherencia dadaísta en la vertebración de principios creadores en diseño gráfico
}

\author{
The Influence of the \\ Dadaist Inherence on the \\ Structuring of Creating \\ Principles of Graphic Design
}

\author{
Silvia Hernández Muñoz (España) \\ Doctora en Bellas Artes \\ Universidad de Zaragoza \\ Correo electrónico: silviahm@unizar.es
}

\section{Resumen}

En esta investigación se ha propuesto determinar y definir los elementos del protodiseño vanguardista que influyen en el diseño gráfico actual. La tesis plantea que existe una práctica del humorismo en la creación de carteles, folletos, libros y tipografías en el origen del diseño gráfico. El proyecto precisa realizar un recorrido por las primeras

\begin{abstract}
This research determines and defines the elements of the avant-garde proto-design that have influence on the current graphic design. The thesis establishes that there is humor when creating posters, brochures, books, and typography related to graphic design. This project is an overview of the first graphic design manifestations from the point of view that humor
\end{abstract}

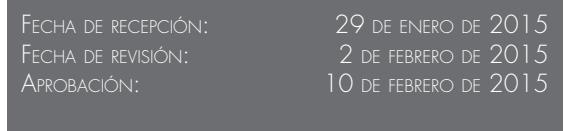

FECHA DE RECEPCIÓN: APROBACIÓN:

10 DE FEBRERO DE 2015 
manifestaciones de diseño gráfico de las vanguardias artísticas desde la perspectiva de que el humorismo no es un elemento más de la estética de vanguardia, sino una cualidad constitutiva del arte nuevo. Para ello, se ha realizado un estudio histórico cualitativo-constructivista de todas las muestras del diseño gráfico en la etapa dadá, que incluye las menos relevantes y las que están más próximas al contexto artístico.

Se concluye concluir que el humorismo en diseño gráfico está muy próximo al ingenio visual y al ludismo y que opera como sentimiento vitalista y de crítica. Además el humor vanguardista surge como recurso de rechazo a las formas anteriores, como elemento de ridiculización, de burla, de parodia, de sarcasmo... y se sintetiza en unas formas gráficas concretas. Las tipografías en libertad, que surgen como elemento perversor de los esquemas compositivos formales. El fotomontaje de imágenes, con fuerte poder comunicativo y satírico en el dadaísmo. El tercer texto, originado por yuxtaposiciones absurdas, da lugar al sinsentido y a lo irreverente, pero crea al mismo tiempo un espacio comunicativo donde surge lo denominado "el tercer texto", espacio propicio para la metáfora.

Palabras clave: diseño gráfico, dadaísmo, humor, subversión, tercer texło. is not another element of the avant-garde aesthetic, but a quality that is part of new art. For this reason, we carried out a historic qualitative-constructivist study -that includes relevant and irrelevant samplesof every graphic design sample.

It was possible to conclude that humor in graphic design is linked to visual and ludic inventiveness that act as vital and critical feelings. In addition, avant-garde humor appeared as a way to reject the previous elements of mockery, parody, and sarcasm and is synthetized in concrete graphic expressions: free typographies that were created as an element that changed formal composing schemes; image photomontage, with a strong satirical and communicative element within the Dadaism; and the third text, that was originated by absurd juxtapositions, originates senseless and irreverent elements, but creates at the same time a communicative space where the "third text" (favorable space for metaphors) appears.

Keywords: Graphic design, Dadaism, humor, subversion, third text. 


\title{
La influencia de la inherencia dadaísta en la vertebración de principios creadores en diseño gráfico
}

\author{
The Influence of the \\ Dadaist Inherence on the \\ Structuring of Creating \\ Principles of Graphic Design
}

\author{
Silvia Hernández Muñoz (España) \\ Doctora en Bellas Artes \\ Universidad de Zaragoza \\ silviahm@unizar.es
}

\section{Introducción}

Marcel sugirió que yo hiciera un cartel anunciando el evento. De los muchos que esbocé, seleccionó una figura filiforme haciendo un palmo de narices al universo, y pasaron cincuenta años antes de que yo supiera que le gustaba por la libertad que expresaba.

En un café de Coney Island, Beatrice Wood se reúne con Duchamp y realiza algunos dibujos para el cartel que anuncia el baile de apertura The Blindman's Ball de la Exposición de los Independientes, aquella en la que Duchamp -entre otros objetos-presenta el polémico urinario y lo titula Font, en esta exposición de más de 2000 obras de artistas europeos y estadounidenses. 
La obra de Duchamp, no sin encerrar una burla y una provocación consciente, al igual que el cartel, transvasa los círculos sociales artísticos y trasciende a la historia del arte como el ícono que mejor define al movimiento artístico dadá. Sin embargo, el contexto social y artístico de un movimiento es más ancho y engloba muchos otros elementos que no se recogen en un rápido repaso a la historia. Representaciones teatrales, actos culturales que no quedan fijados; algunos de ellos no permanecen por estar sujetos a una temporalidad muy limitada, es el caso de nuestra investigación, los carteles, folletos, panfletos o también llamados efímera.

El modo de una Pathosformel, la representación de una emoción, no es un tema de un movimiento concreto, sino una forma icónica que va pasando de movimiento en movimiento. Se trata de una convención social, de un acuerdo comunicativo. Si trazamos una línea desde la Antigüedad clásica, es en el teatro donde encontraríamos los inicios de este acuerdo comunicativo para representar el humor. La comedia antigua, desde Aristófanes hasta Terencio, o la sátira proporcionaban una serie de topoi cómicos que podían ser transpuestos al campo de la visualidad mediante la creación de íconos en las pinturas o esculturas que llevaran a la risa al espectador. El transvase de formas se transmite a lo largo de las generaciones que construyen progresivamente un horizonte de civilización, atraviesa etapas de latencia, de recuperación, de apropiaciones entusiastas y metamorfosis. En ocasiones, pasa a las tipografías grotescas, escenas cómicas de Brueghel el Viejo o los enanos de Velázquez. Tendría una continuidad o a carteles que anunciaban los circos de fenómenos de seres deformes, al teatro del absurdo o a mil y una representaciones publicitarias a partir de las vanguardias artísticas. Pues el humor y la risa visual es un recurso prestado que le viene muy bien a la publicidad como argumento comunicativo.

Abrir una línea de investigación inexplorada y más en un tema tan difícil de acotar como es el humor, y además aplicado al diseño gráfico, no ha sido una tarea fácil. Pues en el cuerpo filosófico tampoco el humor es un tema principal, unido a que los investigadores dentro del diseño gráfico proceden en su mayoría del ámbito profesional y somos muy pocos los que trabajamos por dar un cuerpo teórico a este campo.

En nuestra investigación nos ha interesado particularmente cómo, a 
través de la Pathosformel del humor, por medio de su aparente banalidad, el discurso gráfico arriesga en la exploración y representación de prácticas, comportamientos y visiones del mundo. El humor está actuando como una "licencia" para mostrar comportamientos sancionados en un lenguaje serio, habilita lo prohibido y opera liberando una cuota de presión, pero su mensaje no es banal, siempre encierra una reflexión.

\section{Metodología}

La investigación, de carácter histórico, sigue una estrategia metodológica cualitativo-constructivista, como establece Belmonte (2002, p. 27). Para ello, hemos recopilado información exhaustiva del ejercicio del diseño gráfico en la etapa de las vanguardias artísticas y hemos seleccionado aquellas que consideramos próximas al tema de nuestra investigación. Y, entendiendo que en la investigación cualitativa no solo son relevantes las muestras directas, sino todo lo que acontece en el contexto, hemos investigado en las actividades artísticas de los protagonistas de las vanguardias, sobre todo de los que ejercen al mismo tiempo la profesión de diseñadores o reciben encargos; hemos indagado en procesos técnicos de creación del diseño y de la tipografía en la etapa de las vanguardias artísticas; hemos analizado en los efectos de este diseño vanguardista y los textos, manifiestos y actuaciones que revelan un contexto social lúdico, humorístico e irreverente. En consecuencia, las principales fuentes de información de la metodología constructivista empleadas son la observación crítica, la indagación en profundidad y el análisis de documentos. Adoptando los criterios de credibilidad, transferibilidad, dependencia y confirmabilidad enumeradas por Belmonte Nieto. La investigación cualitativa, indica en su introducción Álvarez-Gayou (2003, p. 27), abarca todos los escenarios y por esta razón en ocasiones hemos recurrido al arte, y algunos procesos experimentales en imprentas que no son estrictamente diseño gráfico. 


\section{La influencia de la inherencia dadaísta en la vertebración de principios creadores en diseño gráfico}

Dadaísmo $^{1}[\ldots]$ Por primera vez se confabulaban en el insulto, llenos de buen humor.

Gómez de la Serna (1988, p. 262)

Dadá comenzó como un movimiento anarquista de oposición a los valores sociales imperantes y al absurdo de la Primera Guerra Mundial. El humor, la antiseriedad, la burla y la ironía serán el comportamiento habitual de dadá. Al reírse de la moralidad, de la religión, de la burguesía, del Estado y de la patria, el dadaísmo es transgresor y provocador. Francis Picabia escribe en Los placeres de dadá:

Dadá tiene placeres como todo el mundo. El principal papel de dadá es verse en los otros. Ya que dadá excita la risa, la curiosidad o la cólera. Como son tres cosas muy simpáticas, dadá está muy contento. [...] Dadá está más contento cuando se ríen de él sin preparación. Siendo el Arte y los Artistas unos inventos

1 Las cursivas son del autor. muy serios sobre todo cuando esto resalta lo Cómico, venimos a lo cómico para reír. Reímos, pues, para burlarnos de nosotros. Dadá está muy contento (León, 1982, p. 102).

Uno de los objetivos de nuestra investigación es evidenciar un humorismo innato en las vanguardias artísticas europeas y es este movimiento el que lo representa con mayor virulencia. Como veremos más adelante, el humorismo dadaísta aparece representado en la deconstrucción tipográfica, en la no relación del texto y la imagen y en la deconstrucción de la propia imagen y en la temática a través de la representación de las máquinas, lo grotesco de los dadaístas alemanes o lo escatológico de Merz.

Aparte de la gran ironía que suponen las vanguardias, en el dadaísmo es frecuente el humor satírico, la burla aparece representada en el cartel anunciador de The blindman's ball (el baile del ciego), celebrado en 1917.

El baile conmemoraba el nacimiento de la revista protodadá Blindman, que defendía la liberación artística de reglas y convenciones para innovar libremente. Como en la figura de Beatrice Wood, haciendo un palmo de narices al universo, los dadaístas eran irreverentes 
e irrespetuosos. Es a través de estas publicaciones, carteles, revistas de pequeño tiraje, anuncios y de su diseño cómo los movimientos de vanguardia llegan a ser conocidos internacionalmente, así como la inmediatez de las innovaciones que se van sucediendo.

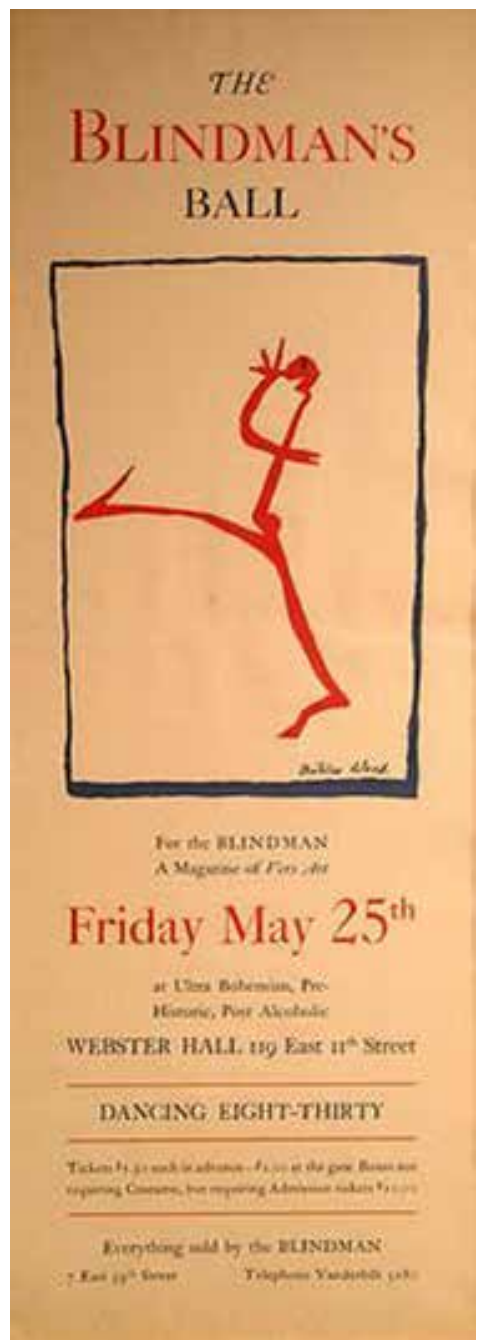

Figura 1: Beatrice Wood, The blindman's ball (el baile del ciego), EE. UU., 1917, cartel, $71 \times 25.4 \mathrm{~cm}$.

\section{El absurdo en la subversión}

\section{imagen-texto. El tercer texto}

La mayor aportación de este movimiento la encontramos en la subversión en la relación imagen-texto o imagen-título. El primer ejemplo está en el origen del dadaísmo, en la exposición del Armory Show ${ }^{2}$ en Nueva York, a la que asistieron diversos artistas europeos, donde Marcel Duchamp presenta Desnudo bajando una escalera n. ${ }^{\circ}$ (Paz, 2008, p. 21), cuya no similitud de la imagen, que correspondía con el estilo cubista, se considera como una asociación irracional con el título. Esta obra obtuvo burlas en la prensa, lo que manifiesta la percepción de una incongruencia, aunque adelantamos aquí lo que después dirían los ultraístas españoles acerca de estas viñetas en las revistas satíricas: "El propio ultraísmo ya es irónico y absurdo, absténganse de burdas bromas".

2 En la armería del $69^{\circ}$ Regimiento de Nueva York se han celebrado muchas exposiciones de arte, pero el Armory Show da nombre a la «International Exhibition of Modern Art» que tuvo lugar entre el 17 de febrero de 1913 y el 15 de marzo y se convirtió en un punto de inflexión para el arte de Estados Unidos. El Armory Show, organizado por Walter Pach, Arthur B. Davies y Walt Kuhn, mostró alrededor de 1.250 pinturas, esculturas y obras decorativas de más de 300 artistas vanguardistas. Entre ellas había muchas obras impresionistas, fauvistas y cubistas. La exposición se trasladó después a Chicago y a Boston. 
Esta perversión sobre el objeto y la palabra se mantendría a lo largo de la obra de Duchamp. Es lo que Mit (2008, p. 70) denomina "el tercer texto", el momento en el que imagen y título se desprenden y este último ya no sirve para ilustrar o aclarar la imagen, sino que añade información, de manera que el mensaje ya no es reiterativo, sino que imagen y texto se completan para contar un concepto. La perversión de Fontaine, de Duchamp, no está en llevar un urinario a un museo, sino en nombrarlo, ya que la imagen deja de ser figurativa. Es el caso del Le Violon d'Ingres, donde la tipografía añadida a la imagen forma lo que podríamos llamar una tercera imagen, donde el texto añadido pervierte la imagen fotográfica.

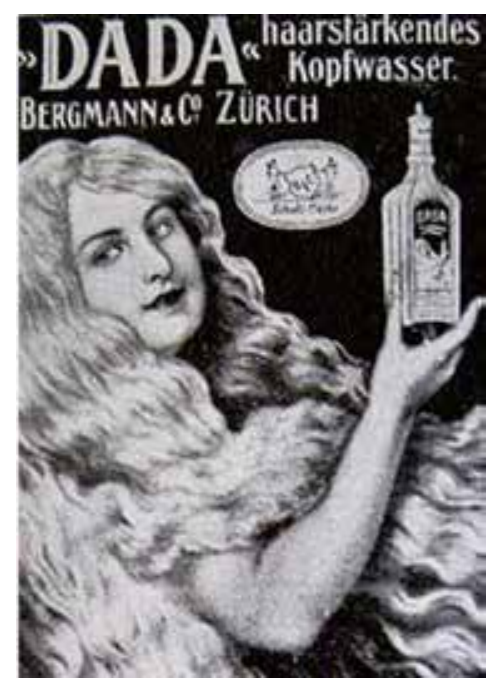

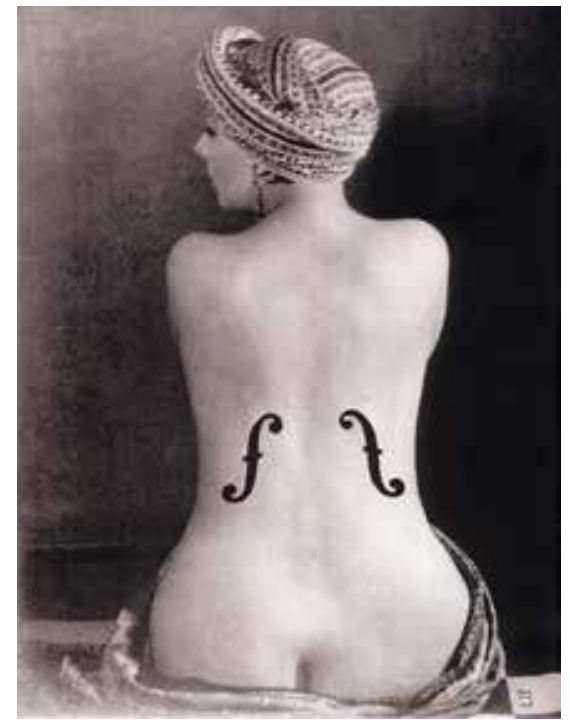

Figura 3. Man Ray, Le

Violon d'Ingres, 1924.

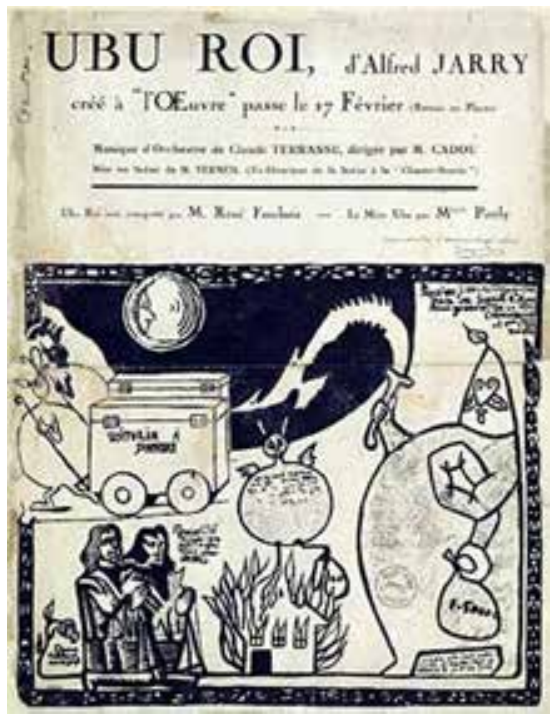

Figura 4. Alfred Jarry, Ubu Roi, París, Mercure de France, 1888.

Figura 2. Cabaret Voltaire. 
Juegos de palabras:

del humor de lo infantil

a lo irreverente para

crear el tercer texto

Gilles Deleuze en Crítica y clínica (1996, pp. 37-39 y 128-140) sitúa a Lewis Carroll en el origen de todo el sinsentido y de todo el mundo irreal que emerge a la superficie y se confunde con lo real, con lo cual se genera una tercera dimensión, como la dimensión patafísica ${ }^{3}$ del también precursor del dadaísmo Alfred Harry, en su obra Ubu Roi, considerada precedente del teatro del absurdo.

El concepto de juego duchampiano proviene de su admiración por el lenguaje plástico de Raymond Roussel o el de Alfred Jarry ${ }^{4}$, quienes le inspiraron sus juegos de palabras. A esta perversión del lenguaje y de los objetos de arte Duchamp y de Picabia le añaden el elemento humorístico para llevarlo, como indica Paz (2008, pp. 145-146), hasta su explosión: “Picabia y yo queríamos abrir un corredor de humor que no tardaría en

3 Disciplina que trata «las leyes que gobiernan las excepciones y explicarán el universo adicional a éste».

TomkINs, Calvin, Duchamp, Barcelona: Anagrama, 2006, pág. 639.

4 Octavio Paz habla de Roussel en términos de humorismo al identificarse el autor con su obra, y en cuanto a Jarry en términos de ironía, al crear una distancia con su obra. desembocar en el onirismo y en consecuencia, en el surrealismo...”.

Este juego reflexivo, irónico y crítico trasciende a la vida cuando inventa un retruécano, construye una máquina o se inventa a Rose Sélavy. La finalidad del movimiento es, en palabras de Breton (2002), sintetizar los conceptos, hasta entonces contradictorios, de sueño y realidad en una realidad absoluta, en una "surrealidad".

\section{La subversión de la imagen como sátira social. El fotomontaje}

El término fotomontaje fue inventado después de la Primera Guerra Mundial, cuando los dadaístas necesitaban un nombre para designar la nueva técnica utilizada para la introducción de fotografías en sus obras. Aragon (1965, p. 29) señala una diferencia fundamental entre las obras de Ernst y el collage cubista:

Para los cubistas, el sello, el periódico o la caja de cerillas que el pintor pega en sus cuadros tienen el valor de una prueba, un instrumento de control de la realidad misma del cuadro. [...] En Max Ernst es distinto [...] el collage pasa a ser un procedimiento poético cuya finalidad se opone por completo al collage cubista cuya intención es puramente realista. 
Rubin (1968, p. 42), en el catálogo de la exposición Dada, surrealism and their heritage, comenta: "La contribución más significativa del grupo berlinés fue la elaboración del llamado fotomontaje, en realidad un fotocollage, puesto que la imagen no era montada en el cuarto oscuro". Y Sergei Tretiakov, sobre todo pensando en Heartfield, escribe en 1936: "Cabe señalar que el fotomontaje no debe ser necesariamente un montaje de fotos. No: puede ser foto y texto, foto y color, foto y dibujo".

En los collages y fotomontajes dadaístas, la utilización de fragmentos de texto es mucho más agresiva que en el cubismo, interesan las propiedades visuales del texto y por eso Hausmann recurrió, en alguna ocasión, a sus propios "carteles poema fonéticos" para realizar un fotomontaje como en El crítico de arte.

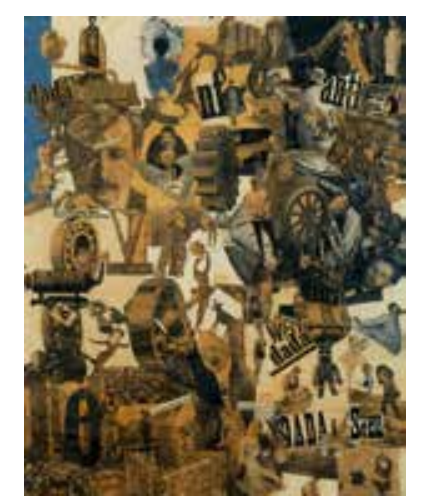

Figura 5. Hannah Höch, Cut with the kitchen knife (Cortado con el cuchillo de cocina), 1919.

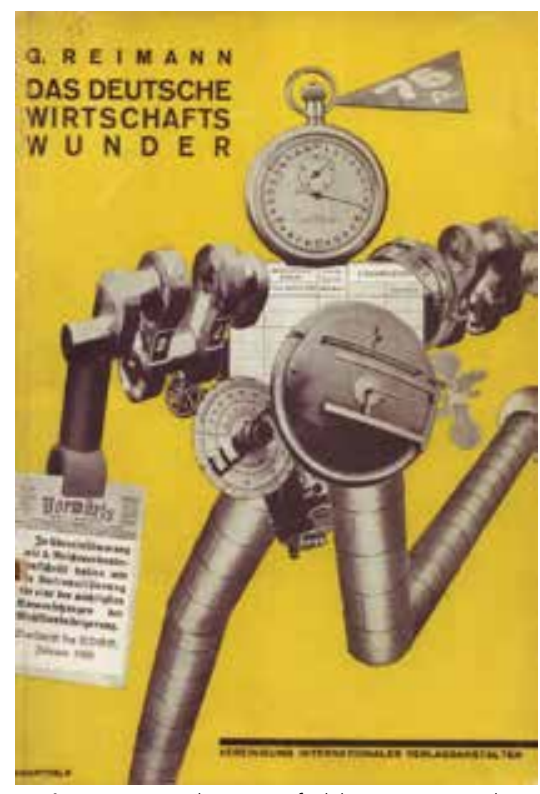

Figura 6. John Heartfield, Das Deutsche Wirtschaftswunder (El milagro económico alemán), cubierta, Alemania, 1927.

Raoul Hausmann y Hannah Höch declararon haber inventado el fotomontaje. Después la República de Weimar y el creciente partido nazi eran el blanco de los ataques de Heartfield, por medio de carteles, portadas de libros y revistas, ilustraciones políticas y caricaturas. Trabajaba con imágenes obtenidas de periódicos o revistas y de manera ocasional encargaba a algún fotógrafo alguna imagen que necesitara. Si bien Marcel Duchamp, Francis Picabia o Tristan Tzara han influido también en el diseño gráfico, la impresión más decisiva fue la del propio Heartfield, junto con los dadás alemanes, Georges Grosz, 
Raoul Hausmann ${ }^{5}$, Hannah Höch, Baader, Hoech y Max Ernst, las maderas de Hans Arp o Kurt Schwitters. La revolución tipográfica, el collage absurdo presurrealista, el fotomontaje y el diseño de las revistas especializadas, únicos vehículos difusores de este movimiento, constituyen hallazgos fundamentales para la evolución del diseño gráfico (Satué, 2004, p. 127).

Durante la etapa dadaísta, Grosz, Heartfield y Herfelde se habían implicado en el movimiento comunista de los trabajadores y habían producido pequeñas revistas políticas a través de Malik Verlag sin referencia al dadaísmo. Entre ellas Jedermann sein eigner Fussball' (Cada hombre

5 Raoul Hausmann en 1931 en una exposición en el Museo de Artes y Oficios de Berlín expone: «[...] Dadá, que era una especie de crítica cultural, no se detenía ante nada. Y es exacto que una gran parte de los primeros fotomontajes perseguía con mordiente ironía los acontecimientos contemporáneos. Pero la idea del fotomontaje es tan revolucionaria como su contenido, su forma es tan subvertidora como la aplicación de la fotografía a textos grabados, que, juntos se transforman en un filme estático. [...] Ellos sabían que una nueva potencia de propaganda se hallaba implícita en este método, y que para desarrollarla y absorberla la vida contemporánea no era lo bastante audaz.

6 Jedermann sein eigner Fussball, revista ilustrada bimensual, publicada por Malik Verlag, la editorial de Wieland Herzfelde, en Berlín. La primera edición de este periódico satírico salió el 15 de febrero de 1919, y fue inmediatamente confiscada por la policía. Incluye dos fotomontajes de John Hearffield en la portada y seis ilustraciones de Geor- su balón de fútbol), figura que después aparecería en las publicaciones dadás. El fotomontaje de Heartfield Wer ist der Schönste? (¿Quién es el más guapo?), supuesto concurso de belleza entre los miembros del Gobierno, cuya imagen aparece desplegada en un abanico, divertimento que tiende al absurdo. El estilo y las fuentes usadas en la portada satirizan la de los rotativos conservadores alemanes.

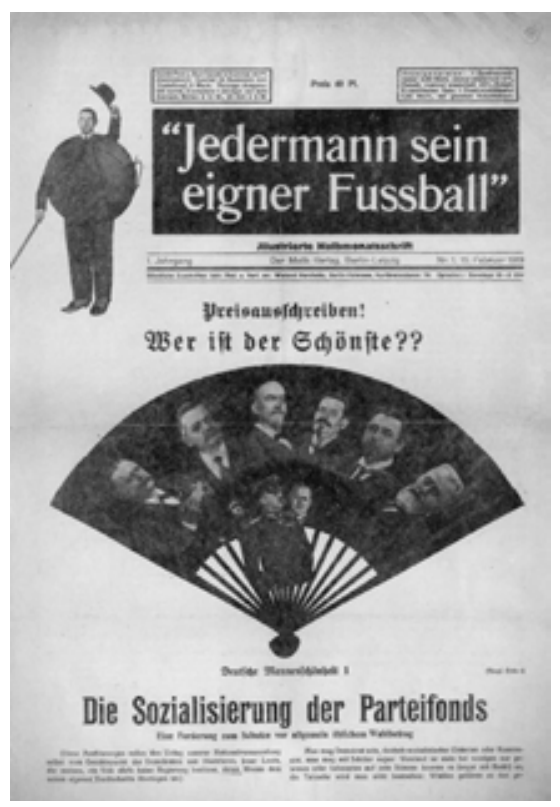

Figura 7. John Hearffield, Jedermann sein eigner Fussball.

ge Grosz, así como escritos de Herzfelde, Walter Mehring o Mynona. También figuran como colaboradores Richard Hüelsenbeck, Erwin Piscator, Karl Nierendorf y J. H. Kuhlemann. 


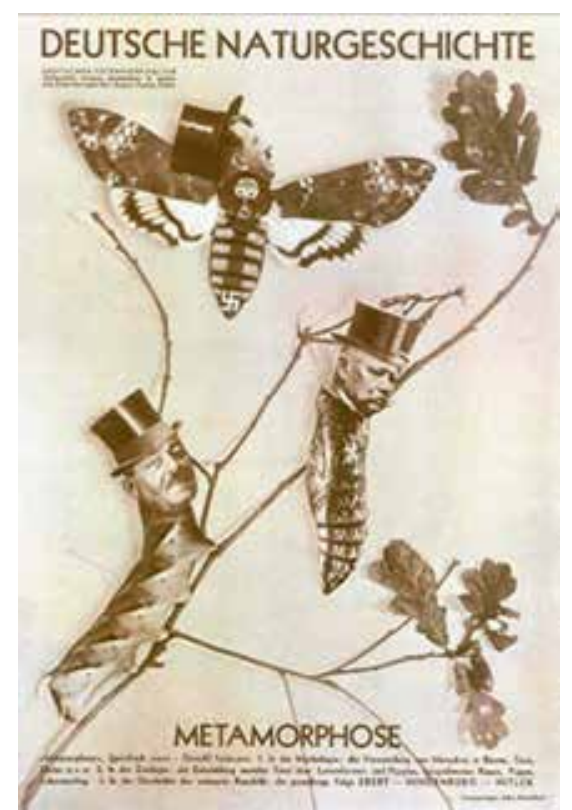

Figura 8. John Heartfield, Deutsche Naturgeschichte. Metamorphose (Historia natural alemana. Metamorfosis). Aiz, 16 de agosto de 1934.

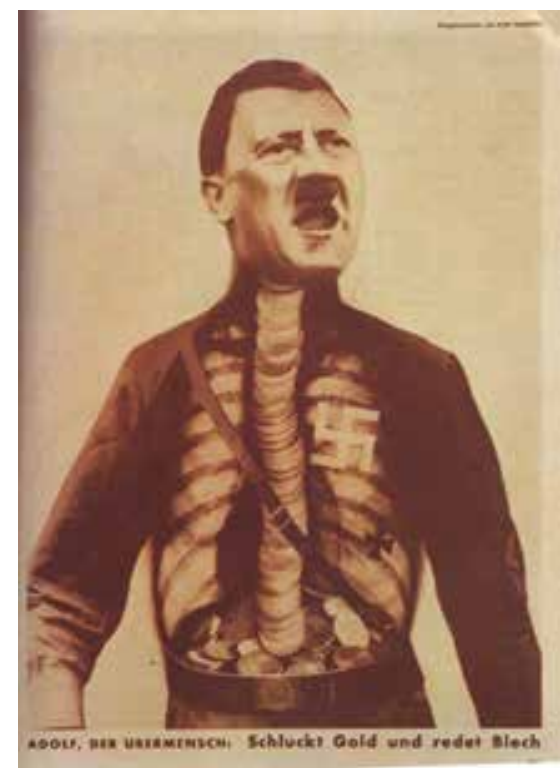

Figura 9. John Heartfield, Adolf el superhombre traga oro y suelta chatarra, 17 de julio de 1932. Aiz 12 it. n. ${ }^{\circ}$ 29. 17 de julio de 1932, p. 675.
Heartfield se convierte en el maestro del fotomontaje, y crea impactantes imágenes para el partido comunista y hace duras acusaciones al Tercer Reich de Hitler, a través del periódico Arbeiter Illustrierte Zeitung. En la obra Metamorfosis: Ebert, Hindenburg, Hitler sostiene que la República de Weimar fue la oruga de la que salió la calavera, Hitler. Todas sus obras son una sátira política. En Adolf der Übermensch (Adolfel superhombre), lo representa como un charlatán. Ades (2002, pp. 56-57) afirma:

Un buen fotomontaje produce el mismo efecto que un buen chiste. Muchos de los mejores chistes de Heartfield - que no por divertidos son menos violentos-suponen una traducción literal de la retórica nazi. Así el texto que figura en la parte inferior iHurra, se terminó la mantequilla!, del 19 de diciembre de 1935, reproduce una cita del discurso de Goering (en su discurso de Hamburgo): el hierro siempre hace fuerte a un país, la mantequilla y la manteca sólo hacen engordar a la gente.

Heartfield representa a una familia a la mesa que come máquinas. Después de dadá se dedicó casi exclusivamente al fotomontaje, trabajó 
para la prensa comunista alemana y diseñó portadas e ilustraciones de los libros publicados por Malik-Verlag, editorial fundada por él y su hermano durante la Primera Guerra Mundial. Todos los artistas que trabajaron el fotomontaje, El Lissitzky, Alexander Mikhailovich Rodchenko, Fritz Stammberger, John Heartfield, han advertido el potencial ideológico de la manipulación de las imágenes que pasan por sus manos y la agitación que pueden llegar a provocar.

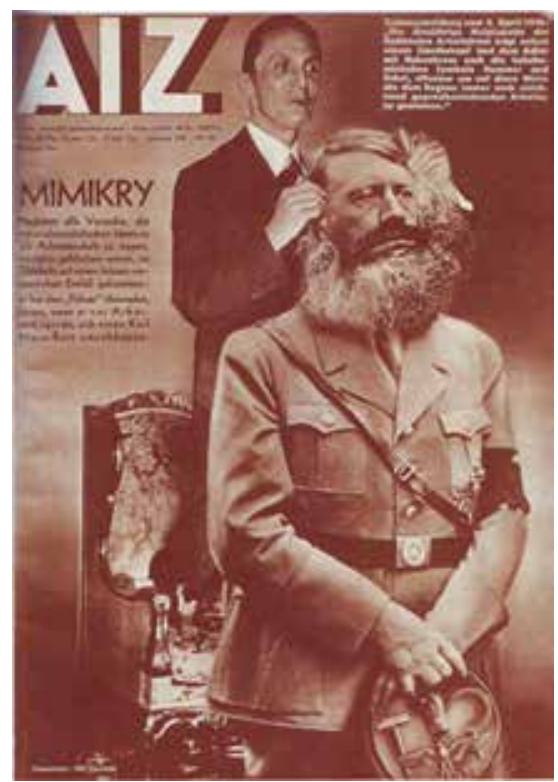

Figura 10: John Heartfield, Aiz 13. n. . 16, 19 de abril de 1934. "Mimetismo".

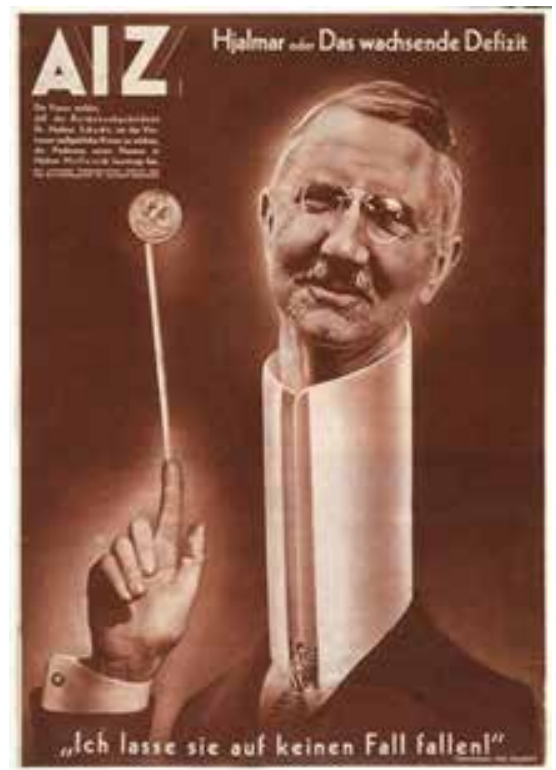

Figura 11: John Heartfield, Aiz, 1934.

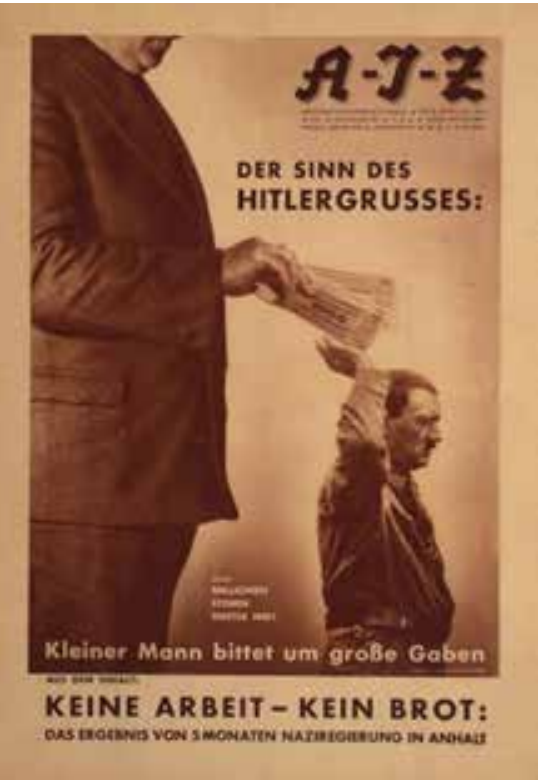

Figura 12: John Hearffield, Aiz, "Razón del saludo». 


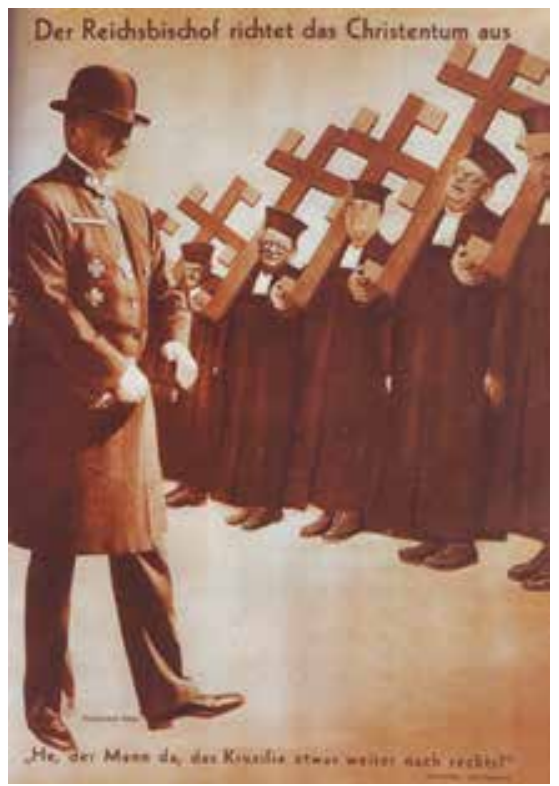

Figura 13: John Heartfield, Aiz 13 n. 3,18 de enero de 1934, "El obispo del Reich adiestra a la cristiandad».

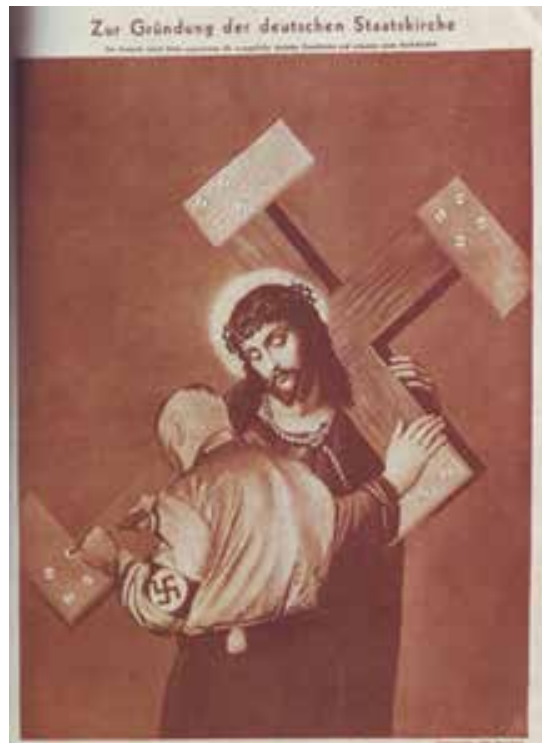

Das Kreur war noch nicht schwer genug

Figura 14: John Heartfield, Aiz $12,{ }^{\circ}{ }^{\circ} 23,15$ de junio de 1933 , La cruz aun no pesaba bastante.

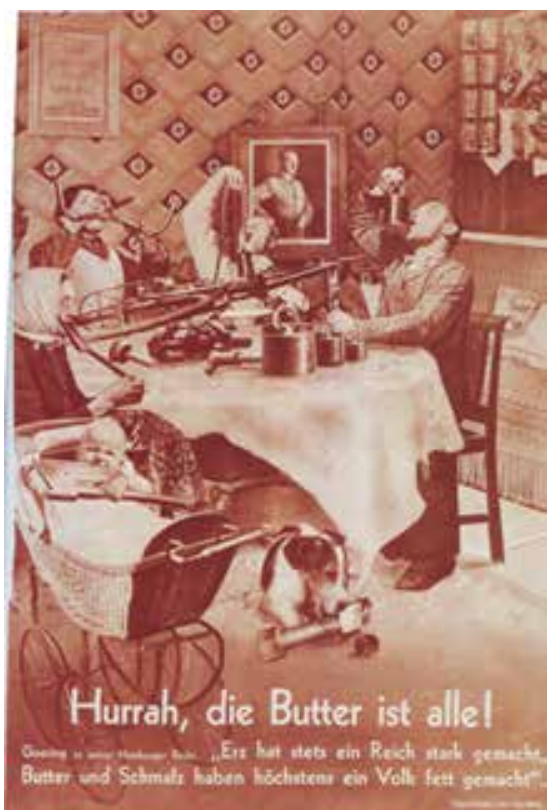

Figura 15: John Heartfield, Aiz, 13

19 de diciembre de 1935 «Hurrah, die Butter ist alle!», [ijurra, se terminó la mantequilla!], 1935

Después el Club Dadá se dispersó. Por un lado, John Heartfield, George Grosz y Otto Dix evolucionaron hacia la nueva objetividad, y otros, como Tristan Tazara, Max Ernst, Man Ray o Francis Picabia, se incorporaron al incipiente movimiento surrealista de París. Horst Rosenberg en el prólogo de la reedición de En avant Dada editado por Raul Hüelsenbeck (2000, p. 21), indica cómo el "Club dadá era una especie de 'guerrilla estética' que había irrumpido en el mundo uniformado de la máquina para hacerlo reventar con su risa”. 
Grosz en un dadaísmo mucho más politizado que sus compañeros franceses o ingleses, quería expresar la brutalidad de la sociedad que conocía, no la de los dramas psicológicos de cada personaje particular. Así introduce una serie de elementos grotescos que, en realidad, parten del género caricaturista. Grosz comparte el gesto anárquico, subversivo, transgresor y revolucionario de los dadaístas. Así lo grotesco, lo revulsivo, se convierte en protagonista del nuevo arte, de la antiestética dadaísta, que lo vinculan con toda la historia estética de lo grotesco, que junto con lo sexual y lo pornográfico completan los elementos liberadores de Freud. Recordemos que este también es un recurso en los chistes. En sus memorias Ein kleines Ja und ein grosses Nein (Un sí menor y un no mayor) niega de un plumazo su etapa de caricaturista, y cuando lo han acusado de ser un mero esteta, ha respondido "Soy un científico, y no un dibujante o un satírico" (Subirats, 1992, p. 18). A través de la editorial Malik-Verlag, de la prensa diaria o de la revista que funda junto con los hermanos Herzfelde, Jedermann sein eigner Fussball (A cada cual su propio balón de fútbol), se coloca en el punto de mira de la extrema derecha. Finalmente el periódico Der blutige Ernst (El sangriento Ernesto) une también dadá y política y cuenta con Carl Einstein, Hülsenbeck y Mehring. En este gupo Grosz era el "propagandada" encargado de inventarse eslóganes como dada ist da (dadá está aquí), dada sieght (dadá vence), dada über alles (dadá por encima de todo), "dada ist sinnlos” (dadá es absurdo).

El humor incluye el ámbito de lo estético como recurso creativo, pero va más allá, es un recurso de pensamiento artístico, es una lucha contra algo establecido, una protesta. Se rebela contra todo lo anterior contra el orden, el canon, el arte...

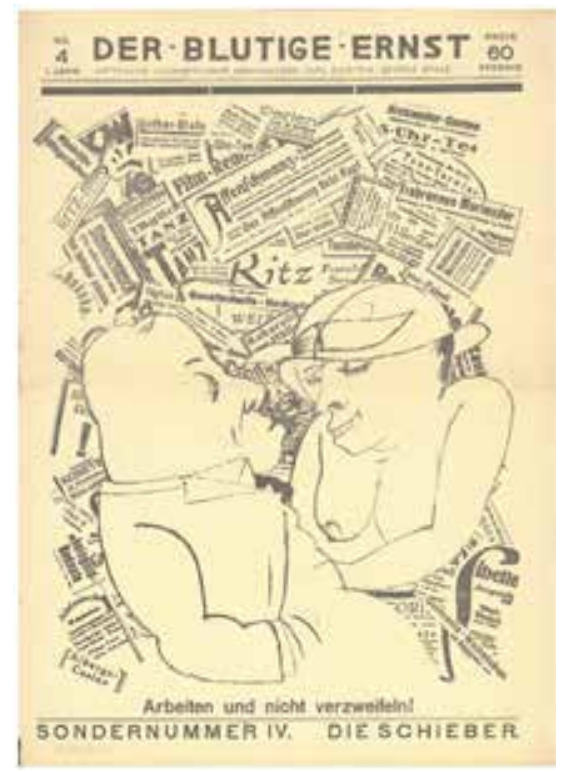

Figura 16: George Grosz, Der Blutige Ernst, n. 4. 

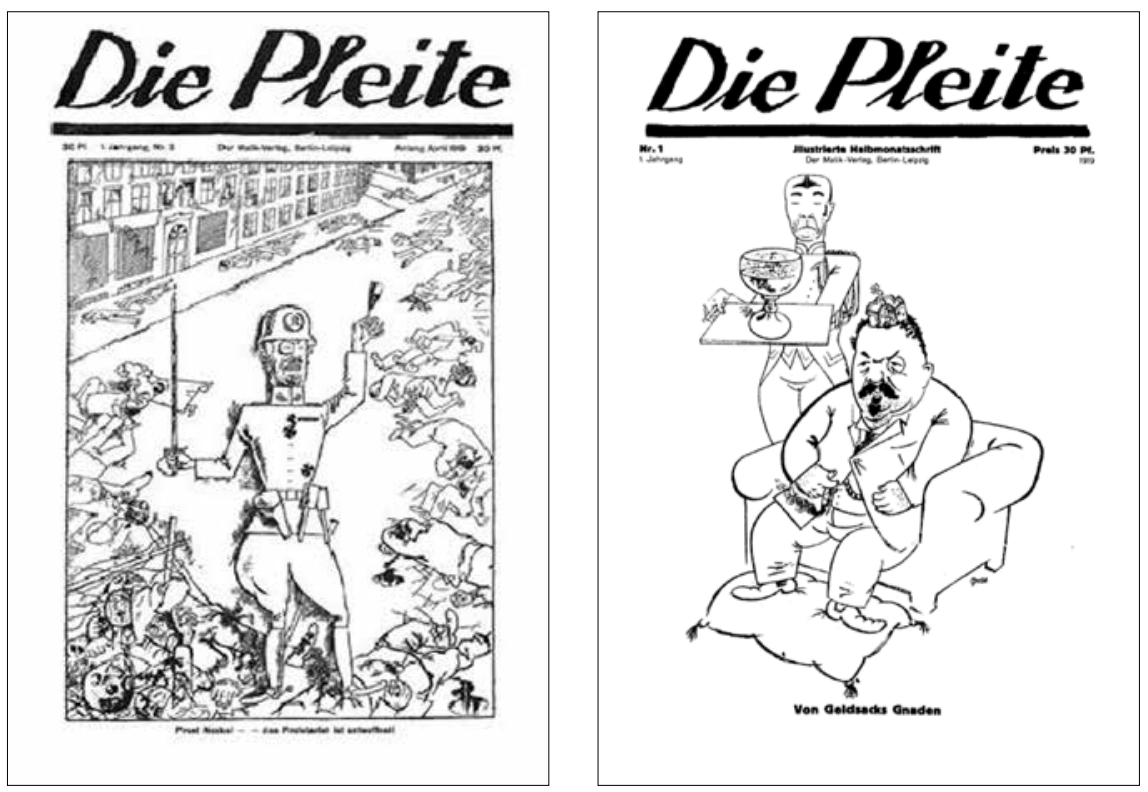

Figura 17 y 18: George Grosz, Die Pleite, Berlin-Leipzig: Malik Verlag, 1919, n. ${ }^{\circ}$ y n. ${ }^{\circ}$

Desde luego, y no solo por afán de modernidad, la plástica vanguardista ha dejado nutrida constancia de esa reducción de lo humano a simple objeto o mecanismo. Los pintores dadaístas sustituyeron al hombre por ingenios mecánicos de dudoso funcionamiento. Schwitters, por ejemplo, reemplazaba el cerebro de una cabeza humana por un engranaje en su collage de 1919 El alienista. También Duchamp en su Grand verre reduce a la Novia y a sus acompañantes en dispositivos mecánicos.

Ortega y Gasset magnifica el aspecto deshumanizador del arte contemporáneo hasta el extremo en el rasgo de su nota esencial y definitoria.
Desde las deformaciones cubistas que reducen al hombre y al entorno a estructuras geométricas hasta las manifestaciones seudohumanas construidas por el hombre, $\mathrm{El} \mathrm{Go-}$ lem, Frankenstein, la autómata de Metrópolis.

\section{La subversión del diseño tradicional}

Se dan dos tendencias en el movimiento vanguardista, un "destructivismo" liderado por movimientos como dadá o el expresionismo, y el movimiento "constructivista". La revisión de la tipografía centrada en los esquemas compositivos y la fotografía como medio habitual de 

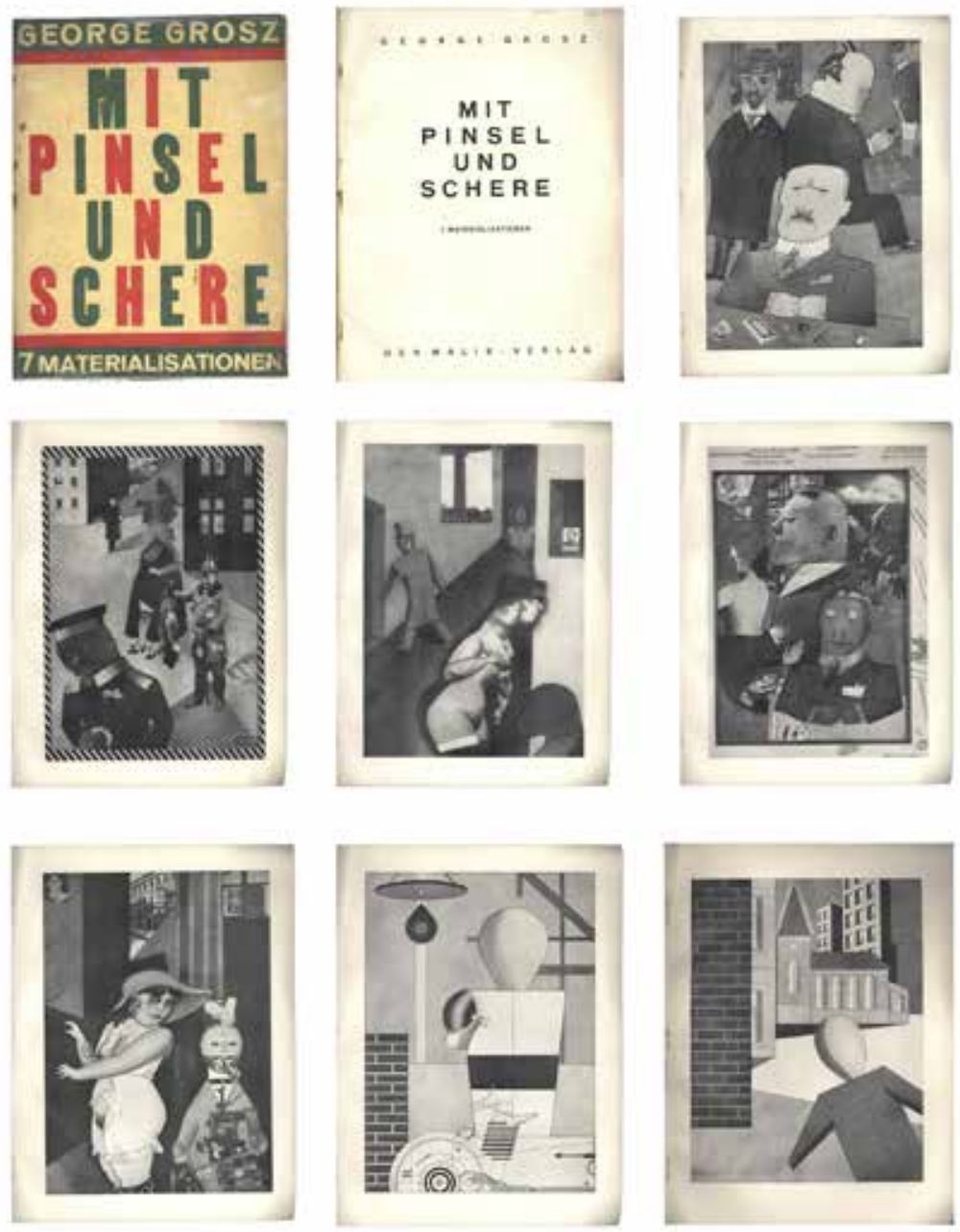

Figura 19: George Grosz, Mit pinsel und schere. 7 materialisationen [Con pinceles y tijeras. 7 materializaciones], cubierta, portada, página de créditos, láminas interiores 1, 2, 3, 4, 5, 6, 77. Berlin-Malik Verlag, 1922

representación visual adquieren gran influencia de Mayakovski y El Lispopularidad, compartida con el cine. sitzky, quienes a través de sus viajes El movimiento soviético trascendió a Alemania y Suiza ejercen el papel rápidamente a Europa debido a la de difusores de la propaganda soviética. El Lissitzky aprovecha sus estancias en Europa para fundar re7 Trad. «Con pincel y tijeras. 7 Materializacionesvistasereditawnsus libros tipográficos, 
exponer sus teorías sobre las revistas de vanguardia, realizar una serie de anuncios para la empresa de tintas Pelikan y divulgar la obra de los vanguardistas.

Tzara y Picabia (1999, p. 25) harían de la rebeldía, la irreverencia y el sacrilegio su método de creación para negar todo arte, empleando un humor anarquizante que rompe la coherencia de la narración y abre la puerta al absurdo con asociaciones disparatadas. Se le unieron los escritores alemanes Hugo Ball y Richard Hülsenbeck y el artista alsaciano Hans Arp. Una vez lanzados los primeros manifiestos, en los que ya se muestran los juegos tipográficos, y publicadas las primeras revistas, otros artistas se identificaron con sus planteamientos, Marcel Duchamp, Picabia, Man Ray y el grupo de Nueva York. Otro foco dadaísta fue durante algunos años Barcelona, otra ciudad "neutral" donde Picabia publicó cuatro números de su revista 391 en la que muestra sus dibujos

8 «DADA; abolición de la lógica, danza de los impotentes de la creación: DADA; de toda jerarquía y ecuación social instalada para los valores por nuestros lacayos: DADA; cada objeto, todos los objetos, los sentimientos y las oscuridades, las apariciones y el choque preciso de las líneas paralelas, son medios para el combate: DADA; abolición de la arqueología; DADA; abolición de los profetas: DADA; abolición del futuro: DADA [...] de esquemas mecánicos y de objetos fielmente copiados como una hélice o una lámpara eléctrica. En Alemania ${ }^{9}$ se manifestó adoptando un carácter político radical con George Grosz, Hüelsenbeck y Heartfield con un empleo de la tipografía secundario; sin embargo, con un aspecto propagandístico que revela conexiones con la vanguardia artística soviética. En Suiza y en Francia, en cambio, fue más lírico con Hans Arp y Tristan Tzara; era el germen del nacimiento del arte abstracto (Tschichold, 2003, p. 42).

Destruyo los cajones del cerebro y los de la organización social: desmoralizar por todas partes y tirar la mano del cielo al infierno, los ojos del infierno al cielo, restablecer la rueda fecunda del circo universal en las potencias reales y la fantasía de cada individuo (Tzara, 1918).

9 Posteriormente, este movimiento es perseguido por el nacismo y por la propia burguesía a la que éste criticaba por considerarla corrupta. Sin embargo apuntaba hacia una auténtica revolución cultural; como indica Satúe, éste ha sido el movimiento del que más recursos ha absorbido el diseño gráfico, de tal manera que sorprende cómo ha depurado el lenguaje virulento antiburgués, lo que permitió la reinserción en la sociedad a este mismo lenguaje al que tan duramente habían rechazado. 

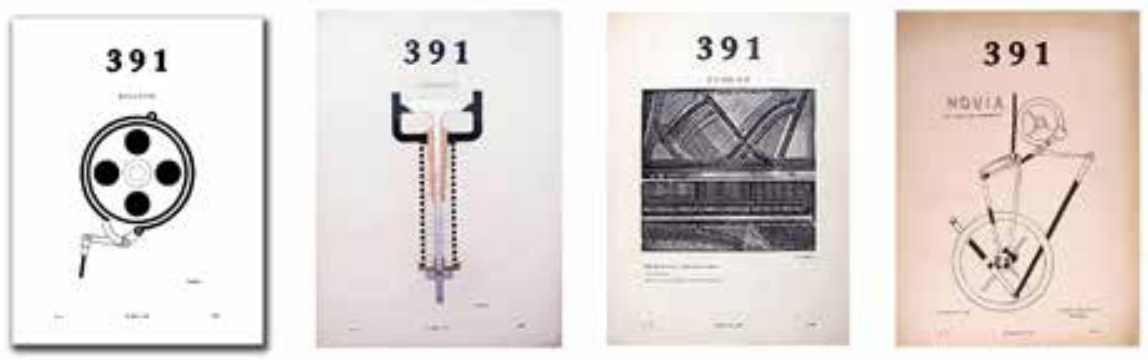

Figura 20: Francis Picabia, 391, Barcelona. Varias portadas de la revista.

El cartel Salon Dada, de Tristan Tzara, sobre una "exposición internacional" que tuvo lugar en junio de 1921, es un ejemplo de promoción gráfica dadaísta. El uso irracional de tipos y tamaños de letra expresa la irreverencia y ejemplifica el empleo de signos comerciales. No hay justificación para la diferencia en los tamaños de letra ni tampoco en la variedad de tipografías. La caja de texto de arriba dice "Nadie debe ignorar al dadaísmo", en otra caja "A los muertos", otras “Quién quiere un par de zapatos de claqué, "Buscando atletas", "Inmovilización”. En la muestra anunciada, Tzara había invitado a escritores a dibujar imágenes, cuyo resultado fueron unas obras carentes de sentido y sin calidad plástica, como era el propósito de las vanguardias hacia el arte.

En Alemania aparecen tres número de la revista más decisiva del dadaísmo, Der dada, de 1919 a 1920, editada por Raoul Hausmann, John
Heartfield y George Grosz; la revista contenía dibujos, temas polémicos, poemas y sátiras tipografiados con una multiplicidad de fuentes y de signos, publicidad de otras publicaciones satíricas dadaístas y de actividades y exposiciones. Un ejemplo de esto es el anuncio de autopublicidad de la revista, que mostramos a continuación, realizado por Heartfield, Kaufen Sie die Bücher des Malic-Verlags und vergessen Sie nicht: DADA Siegt!! (Compra los libros de la editorial Malik y no lo olvides: ¡DADÁ gana!), utiliza el recurso humorístico de la cosificación realizando un personaje con cuerpo de balón, con referencias al juego, que resulta ridículo, cómico y, además, perfectamente trajeado saluda con un sombrero. La broma resulta mucho más suave que los dibujos grotescos de la obra Tragigrotesken der Nacht, de George Grosz, que anuncia más abajo en otra casilla. 
A continuación, mostramos también la publicación de George Grosz que anuncia esta revista Der dada, número 3, Tragigrotesken der Nacht. Traüme, que podríamos traducir por "Noche tragigrotesca. Sueño", en un juego de palabras en alemán que junta la palabra tragedia y grotesco (este último vocablo sustituye a comedia), libro que constituye una sátira a la guerra. Nótese también cómo el uso de la tipografía en Grosz no es más que un recurso cómico para la construcción de la imagen. En el dadaísmo de Colonia se encontraban también Max Ernst con publicaciones como Die Schammade que fundó con Hans Arp y que obtuvo colaboraciones de
Breton, Éluard y Aragó, grupo que derivaría en el dadá parisino con André Breton a la cabeza con la publicación Littérature, fundada con Philippe Soupault y Loius Aragon y con colaboradores como Paul Éulard, Francis Picabia, Ribemont-Dessaignes y Man Ray. Una de las primeras actividades desarrolladas por Tristan Tzara en París fue publicar el Bulletin Dada, concebido como continuación de la revista Dada de Zúrich. En ella destacaban el gran formato empleado, así como la libertad compositiva en cuanto a diseño de la página y de la tipografía. El contenido poseía, como toda manifestación dadaísta, un carácter extremadamente subversivo.
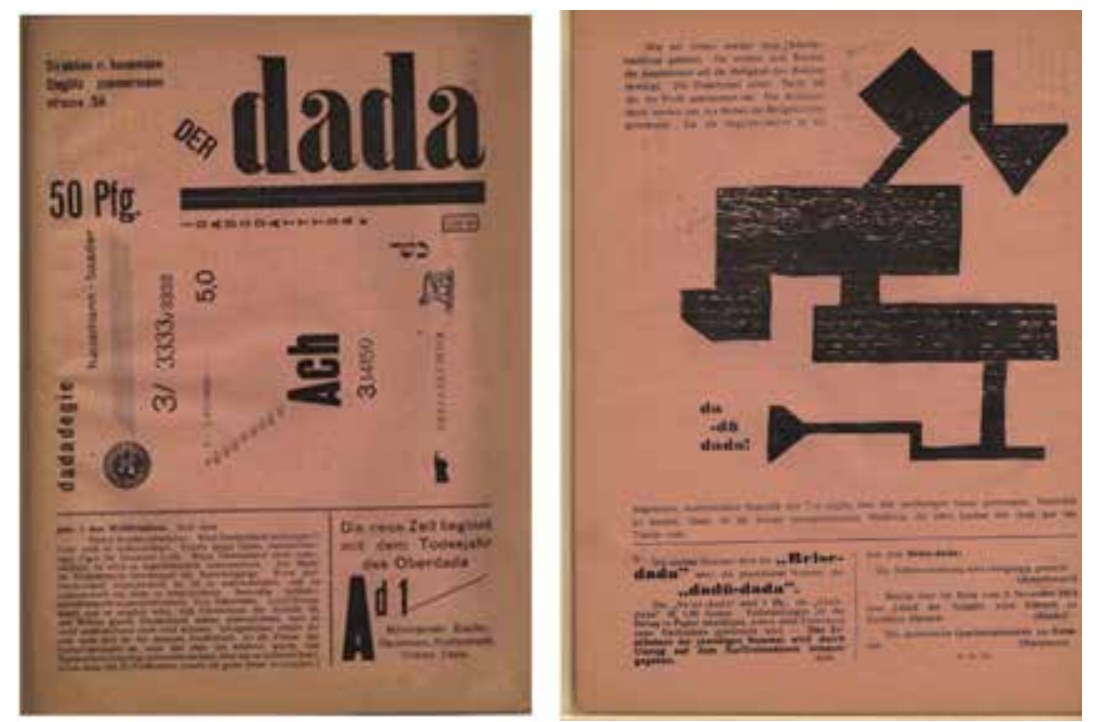

Figura 21: Der dada, n. ${ }^{\circ} 1$. Editado por Raoul Hausmann, John Hearffield y George Grosz, 1919, cubierta y página 5. 

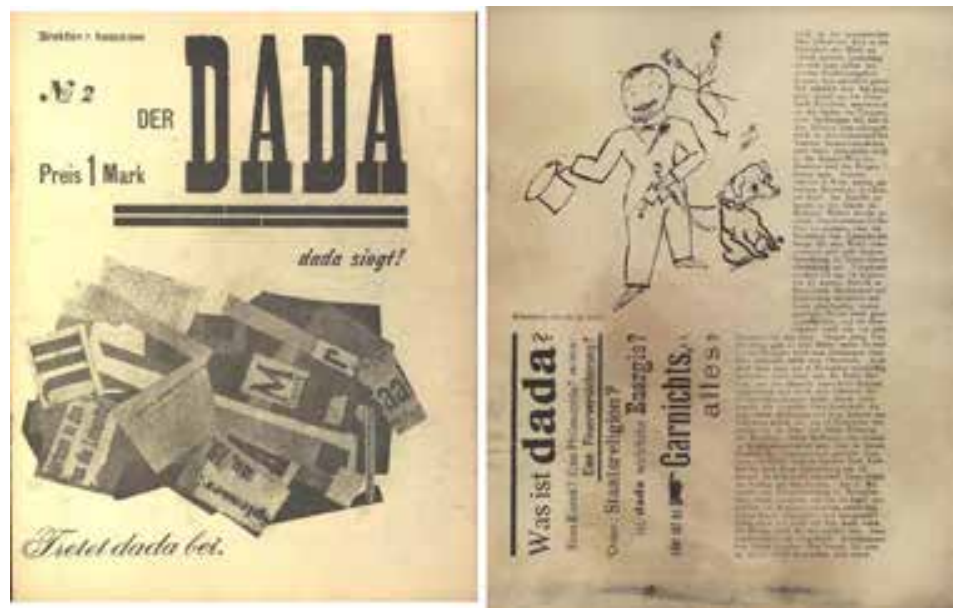

Figura 22: Der dada, n. ${ }^{\circ} 2$, Berlín, 1919, cubierta y página 6.
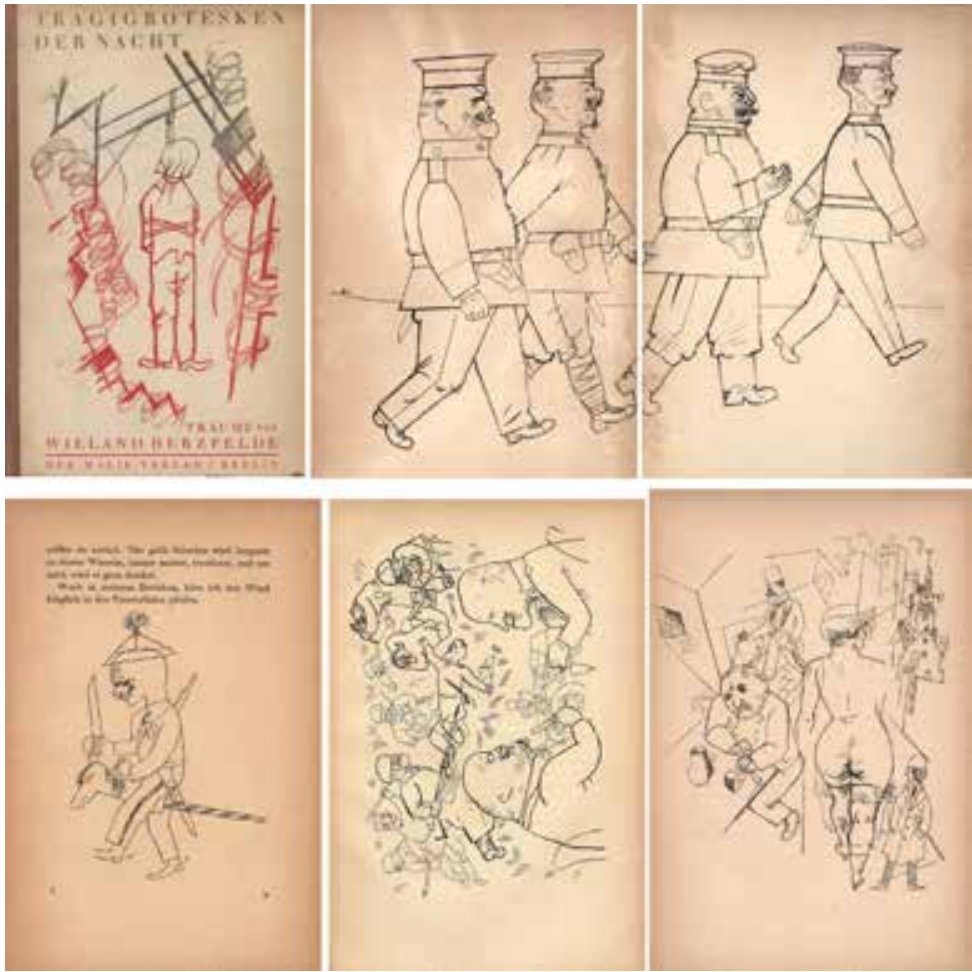

Figura 23: George Grosz, Tragigrotesken der Nacht, cubierta, portada interior 1 y 2. [...] Página 9 , ironiza sobre los soldados montándolos en un ejemplo sobre un épico caballo de madera. (Fig. centro) [...] Página 19, sobre el contenido sexual en el humor grotesco. [...]. Página 14, en la que utiliza la tipografía como recurso expresivo e ironizante. [...] Página 57, dibujos grotescos sobre acciones y juegos militares. George Grosz, Wieland Herzfelde. Tragigrotesken der Nacht: Träume, Berlín: Malik Verlag, 1920. 
La locura, el absurdo, es una búsqueda consciente, nótese, por ejemplo, en el título de la obra de Switters que mostramos anteriormente en imágenes, Memoiren Anna Blumes in Bleie: Eine leichtfassliche Methode zur Erlernung des Wahnsinns für Jederman (Las memorias de Anna Blume: método ligero para el aprendizaje de la locura de cada uno). El dadaísmo ejerce una influencia decisiva en casi todos los campos, sobre todo en el de la publicidad ${ }^{10}$, donde la sorpresa y la apelación al espectador toman importancia como elementos generadores de la atención del público. Por otro lado, la tipografía dadaísta no pretendía rehacer las reglas gramaticales ni crear asociaciones tipográficas como los futuristas, sino más bien, en la línea dadá, descuadrar absolutamente todo orden sintáctico o de lectura desde el propio lenguaje gráfico para convertirse en la subversión absoluta:

10 Manuel Sesma (2004) reconoce cómo esta aplicación de los recursos del dadá, próximos a los recursos publicitarios, "se carga de humor cuando surge en un contexto literario. Dadá actualiza cínicamente lo que el escritor espera de su lector: atención, inteligencia, simpatía u horror, por lo menos complicidad positiva o negativa que se convierten por medio de la ironía y el sarcasmo en fórmulas vacías, ready mades verbales [...]. De hecho los carteles dadaístas son siempre obsesivos, autorreferenciales".
El hombre inteligente se ha convertido en un tipo completamente normal. Lo que nos falta, lo que es de interés, lo que es raro porque posee las anomalías de un ser precioso, la frescura y la libertad de los grandes anti-hombres es

\section{EL IDIOTA}

Dadá trabaja con todas sus fuerzas por la instauración del idiota en todas partes. Pero conscientemente. Y él mismo tiende cada vez más a volverse idiota (Tzara y Picabia, 1999, p. 27).

Pero el más radical desde el punto de vista de las innovaciones tipográficas y conceptuales en este grupo es Ilia Zdavevitch, quien publicó $L e$ dentu le Phare en París en 1923, donde se exilió después de haber trabajado unos años en Tiflis. Allí creó junto a otros artistas, el lenguaje zaum (Knowlson, 1996, p. 217) o trasracional, que utiliza en Ledentu, y que define como un lenguaje en el que las palabras se utilizan no en función de su sentido, sino de su sonido y de su forma, para crear nuevos sentidos e imágenes que correspondan a sus aspiraciones espirituales. Zdavevitch explotó las posibilidades de las letras y símbolos tipográficos, con lo cual contribuyó a la revolución tipográfica 
dadaísta, en obras como la invitación a la Soirée du coeur à barbe (Molins, 2005, p. 45), fiesta organizada en 1923 por el grupo ruso Tchérez, formado por artistas rusos exiliados, donde crea un arco con tipografía, como experimento, comparable a Dlia Golosa, de El Lissitzky en el juego de tamaños de letra, el uso del espacio vacío y la disposición asimétrica. También hace un guiño a Parole in liberta, de Marinetti, tanto en la independencia de las letras individuales como en el movimiento y la variedad de tamaños de letras.

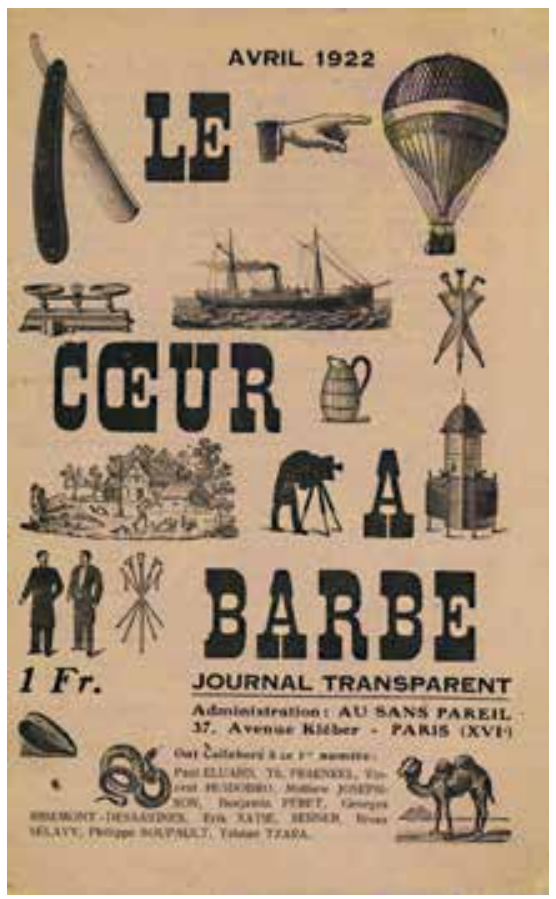

Figura 24: Le Cour à barbe. París: $n$. 1, abril 1922, editada por Tristan Tzara.
El dadaísmo manifestó su crisis y decadencia en París, donde muchos de sus adheridos acabaron enfrentándose entre sí. La parte más enérgica, liderada por André Breton, lanzó en 1924 el Primer manifiesto del surrealismo. En cortante respuesta a la desintegración del dadaísmo, Tzara publica Le coeur à barbe (El corazón con barba), que contenía violentos ataques a Breton, y su simposio modernista en el Congreso de París ${ }^{11}$. Zdanevich diseñó la cubierta consiguiendo la ironía mediante la aplicación de imágenes costumbristas y anticuadas para un tratado nuevo y progresista. Las palabras del título se camuflan con los pictogramas que no tienen relación con el texto y la tipografía antigua confunde visualmente.

11 Congreso de París, una reunión internacional para la determinación de las directrices y la defensa del espíritu moderno, pero la rigidez que mostró en la organización irritó a los dadaístas y supuso la ruptura entre Tzara y Breton y entre estos y Picabia. La guerra siguió hasta el verano de 1923 cuando la representación del Coeur à gaz, de Tzara, acabó, una vez más, en batalla; pero esta vez no entre dadaístas y burgueses, sino entre partidarios de Tzara y de Breton. 

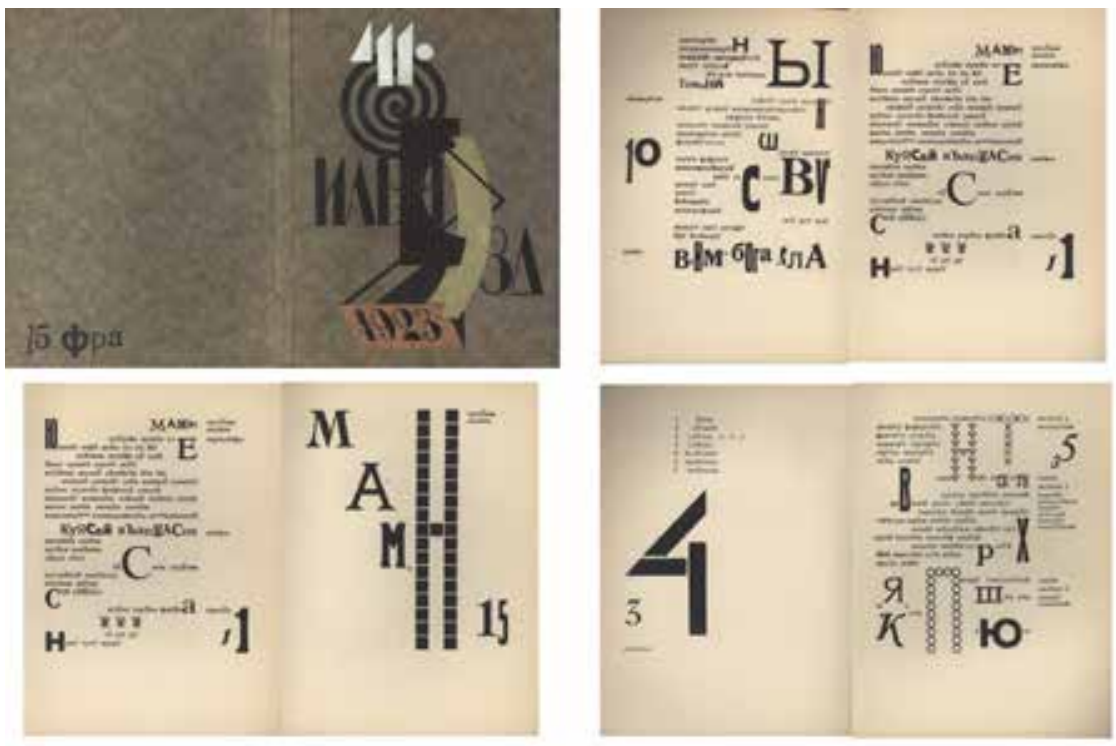

Figura 23: Cubierta, páginas 10, $11,14,15,34,35$. lliazd. Ledantu le phare: Poème dramatique en Zaoum, París, 1923.

\section{Conclusiones}

El objetivo primero de este proyecto ha sido determinar qué elementos del protodiseño vanguardista influyen en el diseño gráfico posterior. $Y$ determinar de igual modo, si existe una práctica del humorismo en la creación de carteles, folletos, libros y tipografías. Nuestro proyecto precisaba realizar un recorrido por las primeras manifestaciones de diseño gráfico de las vanguardias artísticas desde la perspectiva de que el humorismo no es un elemento más de la estética de vanguardia, sino una cualidad constitutiva del arte nuevo.
El humorismo en diseño gráfico está muy próximo al ingenio visual y al ludismo y opera como sentimiento vitalista y de crítica. El humor vanguardista surge como recurso de rechazo a las formas anteriores, como elemento de ridiculización, de burla, de parodia, de sarcasmo.

Una serie de obras resultan claves en nuestra investigación, ya que suponen un reconocimiento consciente del principio de humor que rige las vanguardias. Sus autores reconocen este recurso en sus obras, entre otras, el libro poético Mayakovsky ulybáetsia, 
Mayakovsky smeiótsia, Mayakovsky izdeváetsia (Mayakovsky sonríe, Mayakovsky ríe, Mayakovsky se burla) que reconoce la burla de Mayakovsky hacia todo el arte anterior; el cartel de Beatrice Wood, The blindman's all, realizado por encargo de Marcel Duchamp, junto con la respuesta de Vicente Huidobro a las revistas satíricas de la época que hacían burla de los poemas ultraístas: "Dejaos de burdas bromas, pues el ultraísmo ya es humorístico en sus presupuestos", Francis Picabia en Los placeres de dadá: "Reímos, pues, para burlarnos de nosotros"; el género inventado por Gómez de la Serna que él mismo define: "Greguería = metáfora + humor", y la obra de André Breton, $E l$ humor negro.

En el dadaísmo, el humor, la antiseriedad, la burla y la ironía serán su comportamiento habitual. Se manifiesta en la deconstrucción tipográfica, en la incoherencia entre el texto y la imagen, en la deconstrucción de la propia imagen y en la temática a través de la representación de las máquinas, lo grotesco de los dadaístas alemanes o lo escatológico de Merz. La perversión sobre el objeto y la palabra se manifiesta sobre todo a través de la obra de Marcel $\mathrm{Du}$ champ, donde el texto ya no sirve para ilustrar o aclarar la imagen, sino que añade información, crea un concepto, denominado por Geles Mit como el tercer texto, que lo encontramos al nombrar el urinario como Fontaine, donde la imagen deja de ser figurativa. Esta filosofía de libertad absoluta permite a Duchamp otras subversiones como en L.H.O.O.Q. o los juegos de palabras donde el sentido cambia a otro sentido. Llevaron al absurdo los juegos tipográficos del futurismo y continuaron el concepto del cubismo de las formas de letra como formas visuales concretas.

La impresión más decisiva en el diseño gráfico fue la producida por Heartfield, junto con otros dadás alemanes, como George Grosz o Raoul Hausmann, Hannah Höch y Baader. Los collages y fotomontajes dadaístas utilizaban los fragmentos de texto de forma mucho más agresiva que en el cubismo. Por medio de carteles, portadas de libros y revistas, Heartfield conforma sus ilustraciones políticas y caricaturas sarcásticas, irónicas y destructivas contra la República de Weimar. Las actividades destructivas y exhibicionistas del dadaísmo se volvieron más absurdas y extremas después que la guerra terminó y eventualmente algunos de sus miembros evolucionaron hacia el surrealismo. 
En definitiva, el humor en el diseño gráfico utiliza una serie de recursos de apariencia inocuos para realizar una revisión crítica de nuestro sistema de pensamiento. Hemos estudiado la eficacia del humor en el protodiseño de las vanguardias, hemos analizado los lenguajes que incorpora dicha actitud crítica e irreverente a través de carteles, libros, folletos y tipografías y hemos aplicado este pensamiento humorístico, satírico e irónico al diseño gráfico posmoderno detectando su efectividad como recurso comunicativo, pero también como herramienta reflexiva de la cultura visual.

Lo único que pretende el humor es que, por un instante, nos salgamos de nosotros mismos, nos marchemos de puntillas a unos veinte metros y demos media vuelta a nuestro alrededor contemplándonos por un lado y por otro, por detrás y por delante, como ante los tres espejos de una sastrería (Mihura, 1948, p. 230).

\section{Referencias bibliográficas}

AA. VV. (1995). Kurt Switters (catálogo de la exposición). Valencia: IVAM Centre Julio González.
Ades, D. (2002). Fotomontaje. Barcelona: Gustavo Gili.

Álvarez-Gayou Jurgenson, J. L. (2003). Cómo hacer investigación cualitativa. Fundamentos $y$.

Argan, G. C. (2004). El arte moderno. Madrid: Akal.

Aragon, L. (1965). Max Ernst, peintre des illusions. En Les Collages. París: Hermann.

Belmonte Nieto, M. (2002). Enseñar a investigar. Orientaciones prácticas. Bilbao: Mensajero.

Breton, A. (2002). Manifiestos del surrealismo. Madrid: Visor Libros.

Cirlot, L. (2001). Primeras vanguardias artísticas. Barcelona: PPU Promociones y publicaciones universitarias.

Micheli, M. de (2006). Las vanguardias artísticas del siglo XX. Madrid: Alianza Editorial.

Rincón Igea, D. del, Arnal Agustín, J., Latorre Beltrán, A. y Sans Martín, A. (1995). Técnicas de investigación en ciencias sociales. Madrid: Dykinson. 
Deleuze, G. (1996). Crítica y clínica. Barcelona: Anagrama.

García-Bermejo, J. M. F. (1996). Francis Picabia, Barcelona: Globus.

Gómez de la Serna, R. (1988). Los ismos de Ramón Gómez de la Serna y un apéndice circense. Madrid: Sociedad Estatal para la Acción Cultural Exterior (Catálogo de la exposición, Museo Reina Sofía).

Hausmann, R. (1958). Courrier dadá. París: Le terrain vague.

Huelsenbeck, R. (2000). En avant Dada: l'histoire du dadaisme. Les presses du réel.

Knowlson, J. (1996). The continuing influence of Zaum. Londres: Bloomsbury.

León, M. T. (1982). Memoria de la melancolía. Barcelona: Bruguera.

Mihura, M. (1948). Mis memorias. Barcelona: José Janés.

Mit, G. (2008). El tercer texto. Imagen y relato. Valencia: Universidad Politécnica de Valencia.

Molins, P. (2005). Nunc est Bibendum!...: un mito gráfico desde
1898. Madrid: Michelin España Portugal.

Paz, O. (2008). Apariencia desnuda: la obra de Marcel Duchamp. Madrid: Alianza Editorial.

Rosenberger, H. (2000). En Avant Dada. El Club dadá de Berlín (pról. Raoul Hüelsenbeck). Barcelona: Alikornio.

Rubin, W. (1968). Dada, surrealism and their heritage. Nueva York: Museum of Modern Art.

Satué, E. (2004). El diseño gráfico: desde los orígenes hasta nuestros días. Madrid: Alianza Editorial.

Sesma, M. (2004). Typografismos. Barcelona: Paidós.

Schlemmer, O., Moholy-Nagy, L. y Molnar, F. (1965). Die Bühne im Bauhaus. Mainz: Florian Kupferberg Verlag.

Subirats, E. (1992). Dadá-Grosz. En George Grosz. Obra gráfica. Valencia: IVAM.

Tomkins, C. (2006). Duchamp. Barcelona: Anagrama. 
Tretiakov, S. (1936). John Heart- Tzara, T. y Picabia, F. (1999). Siete field. Moscú: OGIS editora nacio- manifiestos dadá. Barcelona: Tusnal. quets.

Tschichold, J. (2003). La nueva ti- Valdivieso, M. (2005). La bauhaus pografía:manual para diseñadores de fiesta 1919-193. Madrid: Caixamodernos.. Valencia: Campgràfic. Forum. 